\section{REFERENCES}

Aizawa, K. (1939). J. Biochem., Tokyo, 30, 89.

Bate-Smith, E. C. (1949). Symp. biochem. Soc. no. 3, p. 62. Cohen, R. B., Rutenburg, S. M., Tsou, K. C., Woodbury, M. A. \& Seligman, A. M. (1952). J. biol. Chem. 195, 607. Conchie, J. (1954). Biochem. J. 58, 552.

Helferich, B., Winkler, S., Goetz, R., Peters, O. \& Gunther, E. (1932). Hoppe-Seyl. Z. 208, 91.

Hofstee, B. H. J. (1955). Arch. Biochem. Biophys. 59, 398. Ice, C. H. \& Wender, S. M. (1943). J. Amer. chem. Soc. 75, 50.
Jermyn, M. A. (1952). Aust. J. sci. Res. B, 5, 433.

Kerr, L. M. H., Graham, A. F. \& Levvy, G. A. (1948). Biochem. J. 42, 191.

Latzko, E. (1954). Z. PflErnähr. Düng. 66, 148.

Martin, R. W. (1949). Analyt. Chem. 21, 1419.

Nordström, C. G. \& Swain, T. (1953). J. chem. Soc. p. 2764

Roberts, E. A. H. \& Wood, D. J. (1951). Nature, Lond., 167, 608.

Veibel, S. (1941). In Die Methoden der Fermentforschung. Ed. by Bamann, E. \& Myrbäck, K. Leipzig: Thieme.

Veibel, S. \& Lillelund, M. (1938). Enzymologia, 5, 129.

Veibel, S. \& Yang, S. L. (1952). Acta chem. scand. 6, 1366.

\title{
The Metabolism of 8-Azapurines
}

\author{
By J. D. SMITH AND R. E. F. MATTHEWS* \\ Agricultural Research Council Virus Research Unit, Molteno Institute, University of Cambridge
}

\section{(Received 8 October 1956)}

8-Azaguanine inhibits growth or development of many organisms and viruses. These include several transplantable tumours (e.g. Kidder, Dewey, Parks \& Woodside, 1949, 1951; Sugiura, Hitchings, Cavalieri \& Stock, 1950; Law, 1950; Finkelstein \& Thomas, 1951), the chick embryo (Youngner, Ward \& Salk, 1950), Tetrahymena (Kidder \& Dewey, 1949), bacteria (Roblin, Lampen, English, Cole \& Vaughan, 1945; Hitchings, Elion, Falco \& VanderWerff, 1947; Hitchings, Elion, Falco, Russell \& VanderWerff, 1950; Lasnitzki, Matthews \& Smith, 1954) and some plant viruses (Matthews, 1953, $1954,1955)$. In many of these systems it has been shown that 8-azaguanine is incorporated into ribonucleic acids (RNA) replacing a proportion of the guanine residues. The amounts of 8-azaguanine

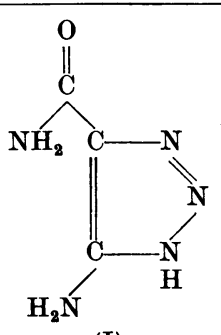

(I)

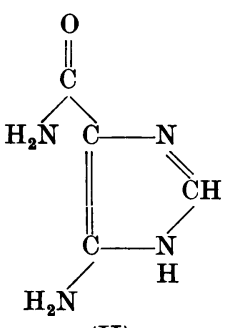

(II) found in RNA are usually low, varying between 1 and $5 \%$ of the guanine content. We have, however, found that Bacillus cereus incorporates 8-azaguanine into its RNA with replacement of up to $40 \%$ of the guanine. With this organism we have studied the distribution of 8-azaguanine in the bacterial RNA.

We have also investigated the effects of similar analogues of purines and their precursors on bacteria

* Present address: Plant Diseases Division, Department of Scientific and Industrial Research, Auckland, New Zealand. and tobacco mosaic virus. These include 8-azaadenine and certain substituted triazoles. 5(4)Amino- $1 H$-1:2:3-triazole-4(5)-carboxyamide (I) is an analogue of 5(4)-amino-1 $H$-1:2:3-imidazole-4(5)carboxyamide (II), the purine precursor described by Shive, Ackermann, Gordon, Getzendaner \& Eakin (1947). Some preliminary results of this work have been reported (Matthews \& Smith, 1954, 1956).

\section{MATERIALS AND METHODS}

8-Azapurines and substituted triazoles. These were gifts from the American Cyanamid Co. 8-Aza-adenosine was a gift from Dr J. Davoll. Guanine and hypoxanthine were commercial products. The purity of all these substances was checked by paper chromatography in several solvents.

\section{Growth of bacteria and viruses}

Escherichia coli. E. coli strain B/r (Witkin, 1951) was grown in synthetic media. Medium $A$ comprised: $\mathrm{KH}_{2} \mathrm{PO}_{4}$, $13 \cdot 6$ g.; $\left(\mathrm{NH}_{4}\right)_{2} \mathrm{SO}_{4}, 3 \cdot 3 \mathrm{~g}$; $\mathrm{MgSO}_{4}, 7 \mathrm{H}_{2} \mathrm{O}, 0 \cdot 4 \mathrm{~g}$.; $\mathrm{CaCl}_{2}$, $10 \mathrm{mg}$.; $\mathrm{FeSO}_{4}, 7 \mathrm{H}_{2} \mathrm{O}, 0.5 \mathrm{mg}$.; glucose, $10 \mathrm{~g}$; $\mathrm{NaOH}$ to $\mathrm{pH} 7$ and water to $1 \mathrm{l}$. Medium $\mathrm{H}$ comprised $\mathrm{Na}_{2} \mathrm{HPO}_{4}, 6 \mathrm{~g}$.; $\mathrm{KH}_{2} \mathrm{PO}_{4}, 3 \mathrm{~g}$.; $\mathrm{MgSO}_{4}, 7 \mathrm{H}_{2} \mathrm{O}, 0 \cdot 2 \mathrm{~g}$; $\mathrm{NaCl}, 0 \cdot 5 \mathrm{~g}$.; $\mathrm{NH}_{4} \mathrm{Cl}, 1 \mathrm{~g}$.; glucose, 0.4 g.; water to 1 l. (Herriott \& Barlow, 1952). In making up these media the glucose was autoclaved separately. The growth rates of the bacteria and their behaviour towards the purine analogues were identical in both media.

A purine-requiring strain of $E$. coli (55) was obtained from Dr E. Wollman of the Institut Pasteur, Paris. This was grown in $H$ medium supplemented with adenine or guanine. Bacillus cereus strain 569 H (Kogut, Pollock \& Tridgell, 1956) was grown on a medium comprising: vitamin-free casein hydrolysate, $10 \mathrm{~g}$.; $\mathrm{KH}_{2} \mathrm{PO}_{4}, 3.5 \mathrm{~g}$.; $\mathrm{MgSO}_{4}, 7 \mathrm{H}_{2} \mathrm{O}$, $0.51 \mathrm{~g}$.; $\left(\mathrm{NH}_{4}\right)_{2} \mathrm{Fe}\left(\mathrm{SO}_{4}\right)_{2}, 6 \mathrm{H}_{2} \mathrm{O}, 4.8 \mathrm{mg}$.; $\mathrm{NaOH}$ to $\mathrm{pH} 7$ and water to 11 .

Bacteria were grown at $37^{\circ}$, either in 61 . bottles with vigorous aeration from an air compressor or in flasks on a rotary shaker. Samples for the isolation of nucleic acid were chilled to $4^{\circ}$, and the bacteria were sedimented in the centrifuge and washed once in $0.14 \mathrm{M}-\mathrm{NaCl}$ or $0.05 \mathrm{M}$-sodium 
phosphate buffer pH 7·1. In experiments where it was necessary to stop bacterial metabolism rapidly the samples were poured into 2 vol. of $90 \%(v / v)$ ethanol made $0 \cdot 1 \mathrm{~N}$ with respect to acetic acid. The cells were centrifuged and washed in acidified $70 \%(v / v)$ ethanol.

Bacterial growth was followed by optical-density measurements of cell suspensions in a photoelectric colorimeter (A. Gallenkamp and Co. Ltd., London) with a blue filter and $1 \mathrm{~cm}$. cell. An optical-density reading of $0 \cdot 1$ corresponded in $E$. coli to $3.0 \times 10^{8}$ cells $/ \mathrm{ml}$, and with $B$. cereus to $0 \cdot 2 \mathrm{mg}$. dry wt. of cells $/ \mathrm{ml}$.

Bacteriophages $\mathrm{T}_{2}$ rand $\mathrm{T}_{2} \mathrm{r}^{+}$were grown on $E$. coli $\mathrm{B} / \mathrm{r}$ in $H$ medium and purified according to Herriott \& Barlow (1952).

Tobacco mosaic virus was grown on Nicotiana tabacum var. White Burley. Solutions of the analogues were sprayed on the plants every 2-3 days for about 14 days after infection (Matthews, 1954). The virus was isolated by heat clarification of the plant sap followed by repeated precipitation of the virus either with ammonium sulphate or by adjusting the preparation to $\mathrm{pH} 3$.

\section{Isolation of bacterial $R N A$}

$E$. coli. The cells were washed in ethanol and acetone and dried in a stream of air at room temp. They were then extracted three times with $2 \mathrm{M}-\mathrm{NaCl}$ at $100^{\circ}$ for $20 \mathrm{~min}$. The combined extracts were deproteinized by shaking with a chloroform-octanol mixture (Sevag, Lackman \& Smolens, 1938) and the RNA was precipitated by the addition of ethanol to $67 \%$. The product usually contained a small amount of deoxyribonucleic acid.

$B$. cereus. Three methods were used for the isolation of B. cereus RNA. Method (1) was similar to that described for $E$. coli and gave a yield of 10-20\% of the total cell polyribonucleotide. In method (2), which yielded about $70 \%$ of the cell RNA, the bacteria were washed in ethanol and acetone, and extracted 2-3 times in $0.1 \mathrm{M}$ sodium citrate buffer ( $\mathrm{pH} \mathrm{7)}$ for $2-3 \mathrm{hr}$. at $100^{\circ}$. The combined extracts were deproteinized and precipitated in $70 \%$ ethanol-water (v/v) adjusted to $\mathrm{pH} \mathrm{3.5}$ with acetic acid. A rather low yield of RNA could be obtained by extraction of the defatted cells with water at $40-50^{\circ}$. Method (3) avoided temperatures above $37^{\circ}$. The cells were stirred in $15 \%(w / v)$ aqueous sodium dodecyl sulphate (Duponol C, du Pont de Nemours and Co.) (pH 7.3) for 4-5 hr. at $37^{\circ}$. The suspension was poured into twice its volume of ethanol and the precipitate was collected by centrifuging and extracted three times in $0.1 \mathrm{M}$-sodium citrate buffer ( $\mathrm{pH} 7$ ) for $10 \mathrm{~min}$. at $24^{\circ}$. The combined extracts were deproteinized and the RNA was precipitated as in method (2). The distribution of 8-azaguanine was similar in all three preparations.

\section{Isolation of deoxyribonucleic acid (DNA)}

E. coli DNA was prepared by the method of Smith \& Wyatt (1951). B. cereus DNA was isolated in low yield by a method similar to that described by Gandelman, Zamenhof \& Chargaff (1952). Any RNA present in the preparation was hydrolysed in $\mathrm{N}-\mathrm{KOH}$ at $20^{\circ}$ for $18 \mathrm{hr}$. The DNA was then precipitated by adjusting to $\mathrm{pH} 3.5$ with $\mathrm{HCl}$ and adding 2 vol. of ethanol and $\mathrm{MgSO}_{4}$ to $0.01 \mathrm{M}$. The precipitate was washed once with $75 \%$ ethanol-water $(\nabla / v)$.

$\mathrm{T}_{2}$ bacteriophage DNA was liberated by 'osmotic shock' (Anderson, 1950) and most of the protein removed by centrifuging. The nucleic acid was precipitated by the addition of 2 vol. of ethanol.

\section{Hydrolysis of nucleic acids and isolation of components}

Paper electrophoresis. The runs were made in the apparatus described by Markham \& Smith (1952a).

Paper chromatography. The solvent mixtures used were: (1), $70 \%$ propan-2-ol-water $(\mathrm{v} / \mathrm{v})$ in an atmosphere of ammonia (Markham \& Smith, 1952b); (2), $65 \%$ propan-2ol-water ( $/ \mathrm{v})$ made $2 \mathrm{~N}$ with respect to $\mathrm{HCl}$ (Wyatt, 1951); (3), saturated $\left(\mathrm{NH}_{4}\right)_{2} \mathrm{SO}_{4}$ in water-M-sodium acetatepropan-2-ol (40:9:1, by vol.) (Markham \& Smith, 1952b).

Estimation of 8-azaguanylic acid in alkaline hydrolysates. RNA or polynucleotide fractions were hydrolysed in $\mathrm{N}-\mathrm{KOH}$ for $18 \mathrm{hr}$. at $20^{\circ}$. The hydrolysate was cooled to $0^{\circ}$ and approximately neutralized with $2 \mathrm{~N}-\mathrm{HClO}_{4}$, and the precipitate of $\mathrm{KClO}_{4}$ removed by centrifuging.

For qualitative or semi-quantitative analysis the mononucleotide mixture was separated by paper electrophoresis in $0.05 \mathrm{M}$-borate buffer ( $\mathrm{pH} 9$ ), where 8-azaguanylic acid migrates ahead of the other nucleotides (Matthews, 1954). Although this separation of 8-azaguanylic acid is adequate for its detection, quantitative estimations are complicated by overlapping of the nucleoside diphosphates produced by the alkaline hydrolysis of some types of polyribonucleotide chains (Markham, Matthews \& Smith, 1954). Consequently for quantitative determinations we used a combination of chromatography and electrophoresis on paper. A portion of the hydrolysate was placed about $6 \mathrm{~cm}$. from a long edge of a sheet $(22 \mathrm{~cm} . \times 45 \mathrm{~cm}$.) of Whatman $3 \mathrm{MM}$ paper, and run as a chromatogram along the long length of the paper in solvent mixture (1). This resolved the mixture into two spots, one containing guanylic and 8-azaguanylic acids and a faster-moving spot containing adenylic, cytidylic and uridylic acids. After drying a strip was cut across the paper to contain both spots, the ends of the strip were dipped in $0.05 \mathrm{M}$-phosphate buffer $(\mathrm{pH} 2)$ and the buffer was allowed to run by capillary movement from both wet ends to cover the areas containing the nucleotides, concentrating them in thin bands. This strip was run in the electrophoresis apparatus for 20-30 min. at about $60 \mathrm{v} / \mathrm{cm}$. This separates guanylic acid from 8-azaguanylic acid, which moves more rapidly towards the anode (Fig. 1). This separation depends on the difference between the dissociation constants of the amino groups of the two substances. Uridylic acid also separated from adenylic and cytidylic acids. By eluting these spots the total ribonucleotides could be estimated.

Ultraviolet-absorbing substances were located by the method of Markham \& Smith (1949), and 8-azaguanine derivatives were detected photographically by their fluorescence in ultraviolet light (Matthews, 1954). The nucleotides were eluted in $0 \cdot 1 \mathrm{~N}-\mathrm{HCl}$ and estimated spectrophotometrically by using the following extinction coefficients: adenylic acid, 13.7 at $255 \mathrm{~m} \mu$; cytidylic acid, 12.9 at $280 \mathrm{~m} \mu$; guanylic and 8-azaguanylic acids, 12.2 at $255 \mathrm{~m} \mu$; uridylic acid, 9.89 at $260 \mathrm{~m} \mu$.

Where necessary the identification of 8-azaguanylic acid was confirmed by separation into 8 -azaguanosine $2^{\prime}$ - and 3 '-phosphates by paper chromatography in the ammonium sulphate solvent, and by hydrolysis in $\mathrm{N}-\mathrm{HCl}$ at $100^{\circ}$ to give 8-azaguanine, which was identified by its ultravioletabsorption spectrum and by paper chromatography.

Ribonuclease hydrolysates. A solution containing 10-20 $20 \mathrm{mg}$. of RNA/ml. and crystalline pancreatic ribonuclease (70 $\mu \mathrm{g} . / \mathrm{ml}$.) was incubated at $50^{\circ}$ for $6 \mathrm{hr}$., followed by $18 \mathrm{hr}$. 

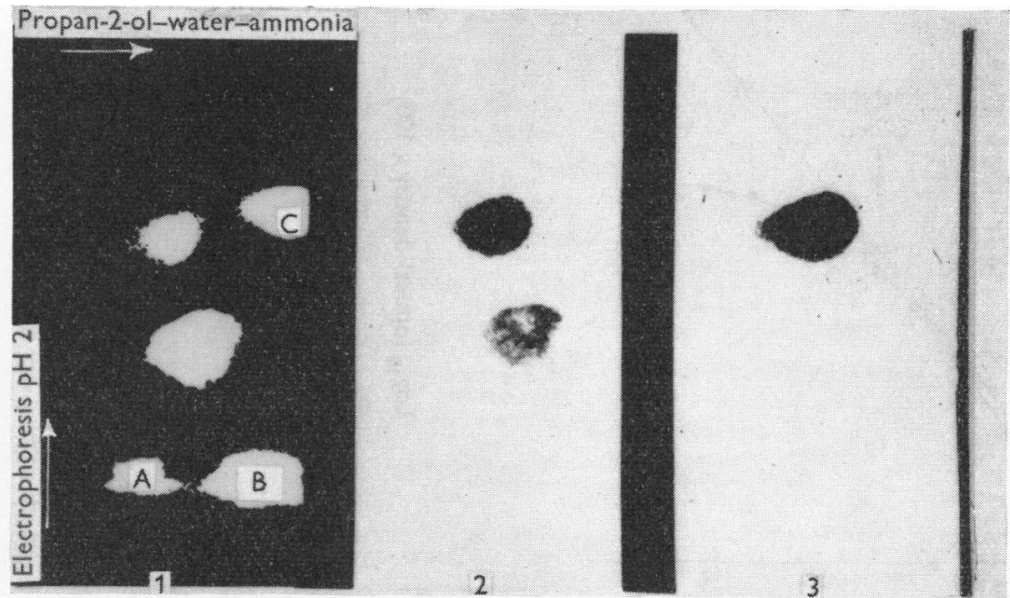

Fig. 1. Separation of guanylic and 8-azaguanylic acid from alkaline hydrolysates of RNA. Paper run as a chromatogram in propan-2-ol-water- $\mathrm{NH}_{3}$ and in the second dimension by electrophoresis in 0.05 $\mathrm{m}$-phosphate buffer (pH 2). Three photographic prints of the same paper showing (1) ultraviolet absorbing spots, (2) spots fluorescent in acid (guanylic acid and 8-azaguanylic acid), (3) spots fluorescent in alkali (8-azaguanylic acid). B is a mixture of adenylic and cytidylic acids. $\mathrm{C}$ is uridylic acid. $\mathrm{A}$ is non-nucleotide ultraviolet-absorbing material present in this RNA preparation.

at $4^{\circ}$ when digestion was completed. During digestion the solution was periodically adjusted to $\mathrm{pH} 7$ with dilute $\mathrm{NH}_{4} \mathrm{OH}$. The hydrolysate was partially fractionated into its components by paper chromatography in solvent mixture (1) in which nucleotides and polynucleotides containing 8-azaguanine move in the same positions as the corresponding guanine derivatives. Bands of cyclic nucleotides and polynucleotides were eluted in water and hydrolysed to mononucleotides in $\mathrm{N}-\mathrm{KOH}$ at $20^{\circ}$ for $18 \mathrm{hr}$., and the proportions of 8-azaguanylic and guanylic acids determined.

\section{RESULTS}

\section{Effects of the analogues on bacterial growth}

The 8-azapurines and substituted triazoles were added to exponentially growing cultures of $E$. coli $\mathrm{B} / \mathrm{r}$ in $A$ or $H$ media and of $B$. cereus. (Additions were made from concentrated solutions of the substances dissolved in the minimum quantity of $\mathrm{NaOH}$.) Subsequent growth was followed turbidometrically for a period of $2-3 \mathrm{hr}$. The normal doubling times of $E$. coli and $B$. cereus in these media are $\mathbf{5 5}$ and $\mathbf{5 0} \mathrm{min}$. respectively.

The type of inhibition observed is illustrated in Fig. 2. Fig. $2 a$ shows the effects of 8-azaguanine and 8-aza-adenine on the growth of $B$. cereus, and Fig. $2 b$ that of 8-azahypoxanthine on $E$. coli $\mathrm{B} / \mathbf{r}$. Growth inhibition increases progressively with time, and except at high concentrations of the analogue does not begin until 1-2 generations have elapsed. Inhibition is annulled if the natural purine is added to the culture with the analogue (Fig. 2b).
$E$. coli and $B$. cereus differ markedly in their response to 8-azapurines and substituted triazoles. $E$. coli is most strongly inhibited by 8 -aza-adenine and 8-azahypoxanthine, to a less extent by 8azaguanine and very slightly by $5(4)$-amino- $1 H$. 1:2:3-triazole-4(5)-carboxyamide (all at concentrations in the range $1-10 \mathrm{~mm})$. 8-Azaxanthine is without effect. $B$. cereus is strongly inhibited by 8 azaguanine and 8-azaxanthine at lower concentrations $(0 \cdot 1-0.5 \mathrm{~mm})$, but 8-azahypoxanthine and aminotriazolecarboxyamide do not affect growth. 8-Aza-adenine is inhibitory only at concentrations greater than $2 \mathrm{~mm}$.

Development of tobacco mosaic virus is inhibited by 8-azaguanine, 8-aza-adenine and aminotriazolecarboxyamide, and not by any of the other analogues when sprayed on plants at concentrations of 5-20 mM. The effects of the analogues on the three biological systems is summarized in Table 1 . 8-Azaisoguanine and two substituted triazoles, which are not analogues of any purine or imidazole known to occur in bacteria or tobacco plants, were not inhibitory in any of the three systems.

\section{Incorporation of 8-azaguanine into nucleic acids}

In following incorporation of 8-azaguanine into bacterial ribonucleic acids 21 . batches of bacteria were grown. The 8-azapurines and triazoles were added to $E$. coli $\mathrm{B} / \mathrm{r}$, to give concentrations of 0.8-2 mM when the culture had reached an optical density of about $0 \cdot 1$, and growth continued until a density of about 0.6 was reached. (8-Aza-adenine, 


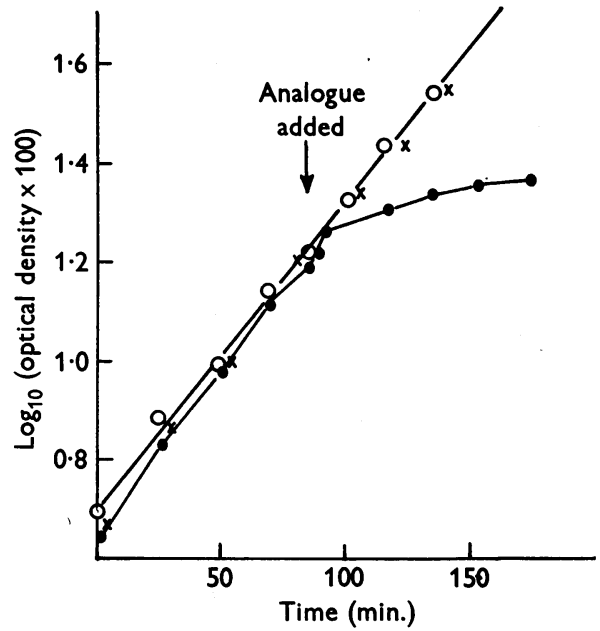

Fig. 2a. Growth of B. cereus in the presence of 8-aza-adenine and 8-azaguanine. $\times, \quad 1.2 \mathrm{~mm}$-8-aza-adenine; 0.6 mM-8-azaguanine; $O$, control with no additions.

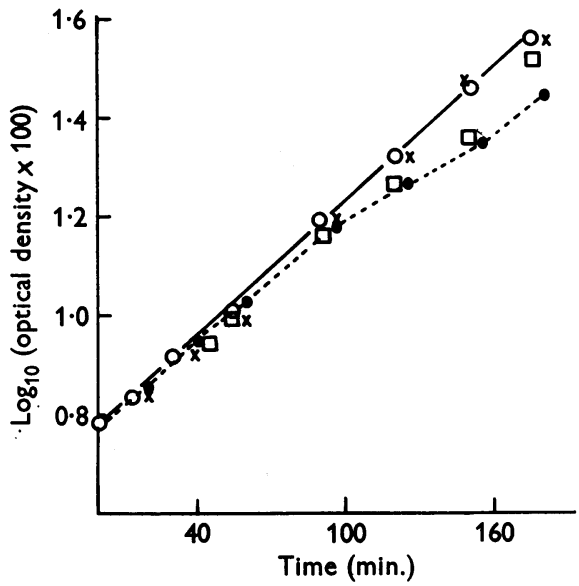

Fig. 2b. Growth of $E$. coli $\mathrm{B} / \mathrm{r}$ in the presence of 8-azahypoxanthine. $\square, 5 \mathrm{~mm}-8$-azahypoxanthine; 10 mM-8-azahypoxanthine; $\quad \times, 5 \mathrm{~mm}-8$-azahypoxanthine +0.5 mM-hypoxanthine; $\mathrm{O}-\mathrm{O}$, control with no additions. The analogue was added at zero time.

Table 1. Correlation between inhibition of growth and incorporation as 8-azaguanylic acid in the ribonucleic acids of tobacco mosaic virus, E. coli and B. cereus

+indicates inhibition or incorporation, - no inhibition or incorporation and 0 not tested.

\section{Compound}

8-Azaguanine

Dimethylamino-8-azaguanine

8-Aza-adenine

8-Azahypoxanthine

8-Azaxanthine

8-Azaisoguanine

5(4)-Amino-1 $H$-1:2:3-triazole-4(5)-carboxylic acid

5(4)-Amino-1 $H$-1:2:3-triazole-4(5)-carboxyamide

5-Hydroxy-1H-1:2:3-triazole
Tobacco mosaic virus

$\overbrace{\text { Inhibition } \begin{array}{c}\text { Incorpor- } \\ \text { ation }\end{array}}$

B. cereus

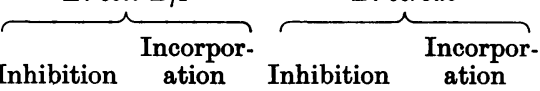

Table 2. Incorporation of 8-azaguanine into ribonucleic acids of various sources

\section{Source}

Tobacco mosaic virus*

Turnip yellow mosaic virus $\dagger$

Pea embryos

Mouse spleen $\ddagger$

Mouse liver $\ddagger$

Mouse tumour (537)

Escherichia coli

Bacillus cereus

Staphylococcus aureus

* Matthews (1954).
Analogue supplied

8-Azaguanine

8-Azaguanine

8-Azaguanine

8-Azaguanine

8-Azaguanine

8-Azaguanine

8-Azaguanine

8-Aza-adenine

5(4)-Amino-1 $H$-1:2:3-triazole-

4(5)-carboxyamide

8-Azahypoxanthine
8-Azaguanine
8-Azaxanthine
8-Azaguanine$$
>20
$$$$
>2
$$

$\dagger$ Matthews (1955).
Guanine residues in RNA replaced by 8 -azaguanine

$$
\begin{gathered}
(\%) \\
3 \\
<1 \\
<1 \\
0 \cdot 5-1 \\
\\
1-2
\end{gathered}
$$


being more inhibitory, was added at a higher cell density.) Conditions for the experiments with $B$. cereus were similar, with the exception that lower concentrations of 8-azaguanine and 8-azaxanthine were used $(0.26 \mathrm{~mm})$.

For experiments on incorporation, tobacco mosaic virus was grown on tobacco plants and the analogues were sprayed on the leaves at concentrations of $10 \mathrm{~mm}$.

The ribonucleic acids of $E$. coli, B. cereus and tobacco mosaic virus grown under these conditions were analysed for their content of 8-azaguanylic acid (Table 2). For comparison we have included in Table 2 the extent of incorporation of 8-azaguanine into the RNA of other organisms. In the RNA of tobacco mosaic virus the 8-azaguanine incorporated quantitatively replaces part of the nucleic acid guanine, so we have expressed 8-azaguanine incorporation as (in molar quantities) $100 \times(8-$ azaguanine $) /(8$-azaguanine + guanine). This is equal to the percentage of guanine residues replaced by 8-azaguanine, and we shall refer to this as the percentage replacement.

The percentage replacement in RNA of $E . \operatorname{coli} \mathrm{B} / \mathbf{r}$ was comparatively low (2-5\%). In RNA from the $B$. cereus cultures $2.5 \mathrm{hr}$. after addition of 8-azaguanine the replacement was $23 \%$, and on further incubation of the culture increased to a maximum of about $40 \%$. This difference in extent of 8 azaguanine incorporation parallels the difference in sensitivity of the two organisms to 8-azaguanine inhibition. 8-Azaguanine was also incorporated into the RNA of the purine-requiring $E$. coli 55 grown in $H$ medium containing $0.2 \mathrm{~mm}$ guanine and $1 \mathrm{~mm}$ 8 -azaguanine; $2-5 \%$ of the nucleic acid guanine was replaced.

Interconversions of 8-azapurines. While attempting to determine whether 8-aza-adenine could be incorporated in bacterial RNA we noticed that RNA of $E$. coli $\mathrm{B} / \mathrm{r}$ grown in the presence of 8 aza-adenine contained 8-azaguanine (about $5 \%$ replacement). 8-Azahypoxanthine and aminotriazolecarboxyamide were also converted into 8azaguanine which was incorporated in RNA of $E$. coli. 8-Aza-adenine and aminotriazolecarboxyamide were incorporated as 8-azaguanine in the RNA of tobacco mosaic virus when these substances were sprayed on tobacco plants during growth of the virus. In $B$. cereus only 8-azaxanthine underwent a similar conversion.

The results in Table 1 show that only those 8 azapurines and triazoles which are incorporated as 8-azaguanine into RNA inhibit growth and that incorporation is in all cases associated with inhibition. Both incorporation and inhibition are prevented by the addition of the natural purine simultaneously with its analogue.

From the properties of synthetic 8-aza-adenine and 8-aza-adenosine the position of 8-aza-adenylic acid in the two-dimensional chromatographic and electrophoretic technique can be predicted. We could not detect any 8-aza-adenylic acid in alkaline hydrolysates of RNA from $E$. coli or $B$. cereus grown in the presence of 8-aza-adenine, 8-azaguanine, 8azahypoxanthine or aminotriazolecarboxyamide.

\section{Deoxyribonucleic acids}

$E$. coli. DNA isolated from $E$. coli strains $\mathrm{B} / \mathrm{r}$ and 55 grown in 8-azaguanine-containing medium was examined for its content of 8-azaguanine. The 8-azaguanine replacement in the RNA of these bacteria was about $5 \%$. Each DNA (1.3 mg.) was hydrolysed in $\mathrm{N}-\mathrm{HCl}$ for $55^{\circ}$ to liberate the purines. The hydrolysates were run on paper chromatograms in solvent mixture (2) with 8-azaguanine as a separate marker. The area corresponding to 8azaguanine and adenine was eluted and the eluate was placed on chromatograms and run in solvent mixture (1) in which 8-azaguanine runs behind adenine. No 8-azaguanine was found. Since $0.5 \mu \mathrm{g}$. of 8-azaguanine could have been detected, the most that could have been incorporated into the DNA would have been less than $0.15 \%$ of the guanine.

$T_{2}$ bacteriophage. In both single-burst and multiple-cycle phage-growth experiments, 8-azaguanine had no significant effect on the yield (measured by plaque counts) of $\mathrm{T}_{2} \mathrm{r}$ or $\mathrm{T}_{2} \mathrm{r}^{+}$grown on $E$. coli $\mathrm{B} / \mathrm{r}$. The 8-azaguanine was added to give concentrations varying from 0.6 to $10 \mathrm{~mm}$ either at the time of infection or $90 \mathrm{~min}$. earlier. A 31 . culture of $E$. coli $\mathrm{B} / \mathrm{r}$ was grown in $H$ medium to a bacterial density of $6 \times 10^{8}$ cells $/ \mathrm{ml}$, when $\mathrm{T}_{2} \mathrm{r}^{+}$to give $10^{8}$ particles $/ \mathrm{ml}$. and 8-azaguanine (to give $1 \mathrm{~mm}$ ) were added simultaneously, and the bacteria were left to lyse. The lysate contained $10^{11}$ phage particles/ml. The phage DNA was isolated and hydrolysed in $72 \% \mathrm{HClO}_{4}$ at $100^{\circ}$ for $1 \mathrm{hr}$. (Marshak \& Vogel, 1950). The hydrolysate was run on chromatograms as described for $E$. coli DNA. No 8azaguanine could be detected. 8-Azaguanine itself was shown to be unaffected by this type of hydrolysis.

$B$. cereus. DNA from $B$. cereus grown in 8azaguanine-containing medium contained small amounts of 8-azaguanine, and from this nucleic acid we isolated a substance with the expected properties of 8-azaguanine deoxyribonucleoside. The DNA was completely freed from RNA by treatment with $\mathrm{N}-\mathrm{KOH}$ and subsequent reprecipitation of the nucleic acid. It was successively hydrolysed with deoxyribonuclease and Crotalus adamanteus venom to the deoxyribonucleosides. The hydrolysate was run on a paper chromatogram in solvent mixture (1) and the band containing deoxyguanosine eluted with water. This material was run on paper electro- 
phoresis on $0.05 \mathrm{~m}$-borate buffer ( $\mathrm{pH} \mathrm{9)}$ with 8azaguanine as a marker. After $0 \cdot 75 \mathrm{hr}$. at about $20 \mathrm{v} / \mathrm{cm}$. the 8-azaguanine marker had migrated $10 \mathrm{~cm}$. The eluted material contained a band of deoxyguanosine which moved $2 \mathrm{~cm}$. and a band fluorescent in ultraviolet light at both neutral and alkaline $\mathrm{pH}$ which moved $6.7 \mathrm{~cm}$. The mobility of this material is less than that of 8-azaguanine ribonucleoside, which forms a borate complex, and corresponds to that expected of the deoxyribonucleoside. After elution from the paper this material was hydrolysed in $\mathrm{N}-\mathrm{HCl}$ at $55^{\circ}$ for $1 \mathrm{hr}$. This treatment hydrolyses purine deoxyribonucleosides without appreciable breakdown of ribonucleosides. The hydrolysate was run on chromatograms in solvent mixtures (2) and (3), where in each case it gave a single spot with the $R_{F}$ values and fluorescence characteristic of 8-azaguanine. We tentatively conclude that the fluorescent material isolated from the electrophoresis run was 8-azaguanine deoxyribonucleoside. It amounted to less than $1 \%$ of the deoxyguanosine in the hydrolysate. The 8 -azaguanine replacement in the RNA from the bacteria was $22 \%$.

\section{Distribution of 8-azaguanine in ribonucleic acids of $\mathrm{B}$. cereus}

In $B$. cereus the high incorporation of 8-azaguanine in its RNA enabled us to determine whether the 8-azaguanine replaced guanine residues at random in the RNA chains, or whether it preferentially occupied certain positions. The RNA was digested to completion with pancreatic ribonuclease. The main products of this hydrolysis are pyrimidine nucleoside, $3^{\prime}$-phosphates and polynucleotides consisting of one or more adjacent purine nucleotide residues terminated by a pyrimidine nucleotide residue. In the intact nucleic acid chain these polynucleotides were joined through their purine nucleotide end to a pyrimidine nucleotide residue. Among the hydrolysis products arealso found small amounts of purine nucleoside, $2^{\prime}: 3^{\prime}$-(monohydrogen phosphates) (cyclic nucleotides) which originate from terminal cyclic purine nucleotide residues linked through their $5^{\prime}$ positions to an adjacent pyrimidine nucleotide residue (Markham \& Smith, 1952c). Thus from the distribution of 8-azaguanylic acid residues among the ribonuclease digestion products some conclusions may be drawn as to the arrangement of these residues in the intact nucleic acid.

The digestion products can be partially fractionated by paper chromatography in solvent mixture (1). The guanine derivatives separate in the following order of decreasing $R_{F}$ value: cyclic guanylic acid, dinucleotides, and polynucleotides in order of increasing size. Polynucleotides containing more than four nucleotide residues do not move. The band containing the cyclic guanylic and 8-azaguanylic acids and a series of bands in the polynucleotide region were eluted, the material was hydrolysed in $\mathrm{KOH}$ and the relative proportions of guanylic and 8-azaguanylic acids were determined.

Table 3 shows the results of analysis of RNA isolated from samples of a $B$. cereus culture taken at various times after the addition of 8-azaguanine. The percentages of 8-azaguanine replacement in the RNA after $5 \mathrm{~min}$. and $2 \mathrm{hr}$. were 3.2 and $22 \%$ respectively. In both cases the cyclic purine nucleotide end groups contained the greatest proportion of 8-azaguanylic acid, although the ratio (cyclic guanylic + cyclic 8-azaguanylic acids)/(total guanylic + 8-azaguanylic acids) in the RNA was about the same for both samples. The percentage of 8 azaguanine replacement increases as the $R_{F}$ value of the polynucleotide in this solvent increases. This means that in the polynucleotide size range of 2-4 residues the proportion of guanine replaced by 8-azaguanine increases with decreasing chain length

Table 3. Percentage replacement of 8-azaguanine in various fractions from ribonuclease digests of B. cereus $R N A$

Bands 1-3 are arbitrary cuts of the paper after chromatography in solvent mixture (1). They cover the region occupied by polynucleotides and are numbered in order of increasing $R_{F}$ value (decreasing chain length). The precise areas cut out in these bands for the $5 \mathrm{~min}$. and $2 \mathrm{hr}$. samples do not correspond.

Time of growth in presence of $0 \cdot 26 \mathrm{~mm} 8$-azaguanine

\begin{tabular}{|c|c|c|c|}
\hline \multicolumn{2}{|c|}{$5 \mathrm{~min}}$. & \multicolumn{2}{|c|}{$2 \mathrm{hr}$. } \\
\hline $\begin{array}{l}\text { Percentage of } \\
\text { 8-azaguanine } \\
\text { replacement }\end{array}$ & $\begin{array}{l}\text { Percentage of } \\
\text { total RNA } \\
\text { guanine and } \\
8 \text {-azaguanine } \\
\text { in band }\end{array}$ & $\begin{array}{l}\text { Percentage of } \\
\text { 8-azaguanine } \\
\text { replacement }\end{array}$ & $\begin{array}{l}\text { Percentage of } \\
\text { total RNA } \\
\text { guanine and } \\
\text { 8-azaguanine } \\
\text { in band }\end{array}$ \\
\hline $\begin{array}{r}3 \cdot 2 \\
2 \cdot 8 \\
\mathbf{4} \cdot 4 \\
\mathbf{7} \cdot 4 \\
17\end{array}$ & $\begin{array}{c}100 \\
60 \\
25 \\
5 \cdot 5 \\
7 \cdot 6\end{array}$ & $\begin{array}{l}22 \\
15 \cdot 3 \\
22 \\
27 \\
69\end{array}$ & $\begin{array}{c}100 \\
39 \\
14 \\
21 \\
6 \cdot 0\end{array}$ \\
\hline
\end{tabular}

Total RNA

Band 1

Band 2

Band 3

Guanosine- $2^{\prime}: 3^{\prime}$-(cyclic phosphate) band
17 . 
Table 4. Ethanol fractionation of B. cereus ribonucleic acid containing 8-azaguanine

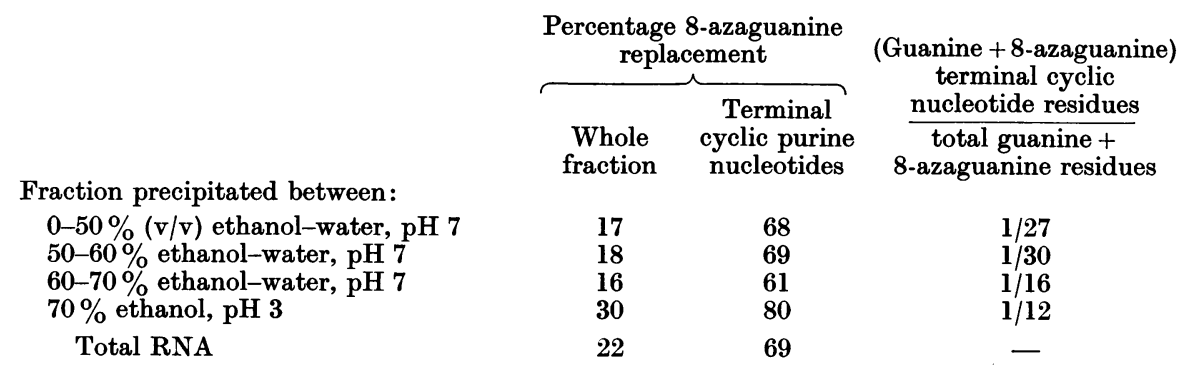

of the ribonuclease-resistant polynucleotides. A similar distribution of 8-azaguanine, both in the polynucleotides and the cyclic nucleotides, was found in RNA from $B$. cereus grown in a medium containing 8-azaxanthine. Two hours after the addition of 8-azaxanthine to give $0.26 \mathrm{~mm}$, the 8 -azaguanine replacement in the RNA was $22 \%$ and that in the cyclic purine nucleotides liberated by ribonuclease was $90 \%$. The same distribution was found in RNA prepared by any of the three methods, including method (3) where heating of the nucleic acid is avoided.

\section{Fractionation of $R N A$ containing 8-azaguanine}

We fractionated the RNA preparations according to polynucleotide chain lengths, either by precipitation with ethanol or by dialysis against concentrated solutions of common salt. For these experiments we used RNA from $B$. cereus grown for $2 \cdot 5 \mathrm{hr}$. after the addition of 8-azaguanine to give $0.26 \mathrm{~mm}$. The percentage of RNA guanine replaced by 8 azaguanine was 22.

Ethanol precipitation. Ethanol was added to an aqueous solution of the nucleic acid ( $15 \mathrm{mg} . / \mathrm{ml}$.) to give an ethanol concentration of $50 \%(v / v)$, the solution was kept at room temperature for $10 \mathrm{~min}$. and the precipitate was collected by centrifuging. Two more RNA fractions were precipitated from the supernatant by successively adjusting the solution to 60 and $70 \%(v / v)$ ethanol-water. A fourth fraction was precipitated from the supernatant of the third fraction after standing $18 \mathrm{hr}$. at room temperature in $70 \%(\mathrm{v} / \mathrm{v})$ ethanol adjusted to $\mathrm{pH} 3$ with acetic acid. Almost all the polyribonucleotides originally present in the solution were recovered in these four fractions.

Dialysis against $2 \mathrm{M}$-sodium chloride. An aqueous solution (10 ml.) containing $15 \mathrm{mg}$. of $\mathrm{RNA} / \mathrm{ml}$. was dialysed against water in a Visking cellulose bag; only traces of material absorbing light at $260 \mathrm{~m} \mu$ passed outside the bag. The solution was then dialysed against three changes of $10 \mathrm{ml}$. of $2 \mathrm{M}-\mathrm{NaCl}$ for $24 \mathrm{hr}$. each time. The combined first two dialysates contained $20-25 \%$ of the material

Table 5. Fractionation of B. cereus ribonucleic acid containing 8-azaguanine by dialysis against $2 \mathrm{M}$-sodium chloride

Undialysed RNA

Material inside the bag after dialysis

Material which passed through the bag

\begin{tabular}{|c|c|}
\hline \multicolumn{2}{|c|}{$\begin{array}{l}\text { Percentage replacement of } \\
\text { guanine by } 8 \text {-azaguanine }\end{array}$} \\
\hline $\begin{array}{l}\text { Whole } \\
\text { fraction }\end{array}$ & $\begin{array}{l}\text { Terminal cyclic } \\
\text { purine nucleo- } \\
\text { tide residues }\end{array}$ \\
\hline 22 & 69 \\
\hline 22 & 57 \\
\hline 28 & 71 \\
\hline
\end{tabular}

originally placed in the sack, as measured by absorption at $260 \mathrm{~m} \mu$. Only traces of material absorbing at $260 \mathrm{~m} \mu$ passed outside the sack in the third dialysis.

To demonstrate that no enzymic breakdown of the nucleic acid was taking place during the dialysis, a portion of the solution remaining inside the bag was diluted with 4 vol. of water and left $26 \mathrm{hr}$. at room temperature. Of this diluted solution $5 \mathrm{ml}$. was then dialysed against $5 \mathrm{ml}$. of $2 \mathrm{M}-\mathrm{NaCl}$ with stirring for $48 \mathrm{hr}$. Less than $2 \%$ of the polynucleotides passed outside the sack (estimated from ultraviolet absorption at $260 \mathrm{~m} \mu$ ).

The polynucleotide fractions obtained by these two methods were analysed for their content of 8-azaguanylic acid and for the proportions of cyclic 8-azaguanylic end groups liberated as cyclic 8azaguanylic acid after ribonuclease digestion. The results are given in Tables 4 and 5. The fraction which was dialysed through the cellulose bag against $2 \mathrm{M}-\mathrm{NaCl}$ and that which was precipitated by $70 \%(v / v)$ ethanol at pH 3 contained higher proportions of 8-azaguanine and of cyclic 8-azaguanylic acid end groups.

\section{Evidence for exchange between guanine and 8-azaguanine in $R N A$ of B. cereus}

When guanine (to give $0.16 \mathrm{~mm}$ ) is added simultaneously with 8-azaguanine (to give $0.33 \mathrm{~mm}$ ) to an exponentially growing culture of $B$. cereus, neither 
growth inhibition nor 8-azaguanine replacement in the RNA occurs. If the guanine is added some time during inhibition by 8-azaguanine, the growth rate, as measured by optical density, increases over about $60 \mathrm{~min}$. until it reaches that of normal bacteria. We measured the changes in total RNA content of the cells and the proportion of 8-azaguanine in the nucleic acid, after the addition of guanine to cultures of $B$. cereus inhibited by 8-azaguanine. Parallel cultures were also run without the addition of guanine. Table 6 shows the results from such experiments. The proportion of 8-azaguanine in the bacterial RNA falls much more rapidly than can be accounted for by dilution with newly synthesized RNA devoid of 8-azaguanine. There is no evidence in these experiments from measurements of turbidity or total cell RNA for any appreciable lysis of the cells during this period. Evidently there is some type of rapid exchange leading to the loss of 8-azaguanine present in the bacterial RNA.

\section{8-Azaguanosine and 8-azaxanthosine in B. cereus}

We examined cells of $B$. cereus grown in 8-azaguanine for their content of non-nucleic acid 8azaguanine derivatives. The bacteria were grown for $2 \mathrm{hr}$. in the presence of $0.26 \mathrm{~mm}$ 8-azaguanine. The washed cells were then extracted in boiling $70 \%(v / v)$ ethanol-water for about 20 min., the

\section{Table 6. Replacement of 8-azaguanine by guanine in the ribonucleic acid of $\mathrm{B}$. cereus}

In each experiment 8-azaguanine to give final concentration $0.33 \mathrm{~mm}$ was added to identical cultures. Guanine, to give a final concentration of $0 \cdot 16 \mathrm{~mm}$, was added to culture 2 after $30 \mathrm{~min}$.

\begin{tabular}{|c|c|c|c|c|}
\hline \multicolumn{5}{|c|}{ Experiment 1} \\
\hline \multirow{2}{*}{$\begin{array}{c}\text { Time after } \\
\text { addition of } \\
\text { 8-azaguanine } \\
\text { (min.) }\end{array}$} & \multicolumn{2}{|c|}{$\begin{array}{l}\text { Percentage of } \\
8 \text {-azaguanine } \\
\text { replacement in } \\
\text { bacterial RNA }\end{array}$} & \multicolumn{2}{|c|}{$\begin{array}{l}\text { Relative amounts } \\
\text { of RNA in the } \\
\text { cultures* }\end{array}$} \\
\hline & Culture 1 & Culture 2 & Culture 1 & Cult \\
\hline $\begin{array}{r}30 \\
60 \\
120\end{array}$ & $\begin{array}{l}13 \cdot 5 \\
16 \cdot 9 \\
28 \cdot 2\end{array}$ & $\begin{array}{r}13 \cdot 5 \\
7 \cdot 7 \\
4 \cdot 0\end{array}$ & $3 \cdot 76$ & $\begin{array}{l}2 \cdot 62 \\
3 \cdot 16 \\
5 \cdot 66\end{array}$ \\
\hline \multicolumn{5}{|c|}{ Experiment 2} \\
\hline \multirow{2}{*}{$\begin{array}{l}\text { Time after } \\
\text { addition of } \\
\text { 8-azaguanine } \\
\text { (min.) }\end{array}$} & \multicolumn{3}{|c|}{$\begin{array}{l}\text { Percentage of 8-azaguanine } \\
\text { replacement in bacterial RNA }\end{array}$} & $\begin{array}{l}\text { Relative } \\
\text { total RNA } \\
\text { contentt }\end{array}$ \\
\hline & Culture 1 & Culture 2 & Culture 3 & Culture 2 \\
\hline 30 & $20 \cdot 8$ & - & - & 1.00 \\
\hline $\begin{array}{r}60 \\
130\end{array}$ & - & $\overline{4 \cdot 1}$ & $\begin{array}{c}38 \cdot 8 \\
-\end{array}$ & $\overline{1 \cdot 27}$ \\
\hline
\end{tabular}

* Based on optical density at $260 \mathrm{~m} \mu$ of ribonucleotides after hydrolysis.

$\dagger$ From RNA pentose estimations on trichloroacetic acid extracts. bacteria were removed by centrifuging and the ethanol extract was concentrated to dryness by vacuum distillation. The residue was taken up in a small volume of water, insoluble material was removed by centrifuging and the supernatant was run on no. $3 \mathrm{MM}$ paper in solvent mixture (1). A band with a bright-blue fluorescence in ultraviolet light $(260 \mathrm{~m} \mu)$ was found in the position where guanosine runs in this solvent. This material was eluted with water and run on paper electrophoresis in 0.05 $\mathrm{m}$-borate, pH 9. Two bands migrated towards the anode and were eluted. The fast-moving band had a blue fluorescence (at $260 \mathrm{~m} \mu$, in acid or alkaline $\mathrm{pH}$ ). It had the ultraviolet-absorption spectrum expected of 8-azaxanthosine $\left(\lambda_{\max }\right.$. $257 \mathrm{~m} \mu$ in $0.1 \mathrm{~N}-\mathrm{HCl})$, gave a positive orcinol reaction and contained no phosphorus. On hydrolysis with $\mathrm{N}-\mathrm{HCl}$ at $100^{\circ}$ for $1 \mathrm{hr}$. the faster-moving band gave a substance with $R_{F}$ values in several solvents identical with those of 8-azaxanthine. The ultraviolet-absorption spectra of this product in $0 \cdot 1 \mathrm{~N}-\mathrm{HCl}$ and $0 \cdot 1 \mathrm{~N}-\mathrm{KOH}$ were also identical with those of 8-azaxanthine. The more slowly migrating material from the electrophoretic runs in borate (pH 9) had a purple fluorescence in ultraviolet light (at acid and alkaline $\mathrm{pH}$ ) and had the ultravioletabsorption spectrum of 8-azaguanosine $\left(\lambda_{\max }\right.$. $255 \mathrm{~m} \mu$ in $0.1 \mathrm{~N}-\mathrm{HCl}$ ). It also contained pentose but no phosphorus, and on hydrolysis with $\mathrm{N}-\mathrm{HCl}$ gave a substance identical with 8-azaguanine both on paper chromatograms and in its ultravioletadsorption spectrum. We conclude that the fastermoving substance is 8-azaxanthosine and the second substance 8-azaguanosine. This is the order in which the two azapurines migrate at pH 9.

The two nucleosides were the only fluorescent materials present in appreciable quantities on the chromatogram in solvent mixture (1). Nucleotides of 8-azaguanine may have been present in ethanol extracts of these bacteria, but, if so, they were in amounts considerably less than those of the nucleosides.

\section{DISCUSSION}

A number of structural analogues of the natural purines and pyrimidines are now known to be capable of replacing the corresponding bases in nucleic acids. These include: 5-chloro-, 5-bromoand 5-iodo-uracils, which can replace thymine in DNA (Dunn \& Smith, 1954; Zamenhof \& Griboff, 1954); 2-thiouracil, which can be incorporated into tobacco mosaic virus RNA (Jeener \& Rosseels, 1953; Matthews, 1956); 8-azaguanine, which can replace guanine in several ribonucleic acids. With most organisms the proportion of ribonucleic acid guanine replaced by 8 -azaguanine is low (1-5\%); but in $B$. cereus this proportion can be as high as $40 \%$. This approaches the extensive incorporation 
observed with the 5-halogenated uracils in $\mathbf{T}_{\mathbf{2}}$ bacteriophage DNA, where $80 \%$ or more of the thymine can be replaced by 5 -bromouracil.

The 8-azapurines and substituted triazoles available to us offered a series of analogues of purines and their possible precursors, all differing from the correspondingly natural derivatives only by the replacement of the $\mathrm{CH}$ group in the 8 position of the purines by a nitrogen atom. The conversion of certain of these analogues into 8-azaguanine, incorporated in RNA, involves only. changes in the substituents on the pyrimidine-ring portion of the molecule, and leaves the triazole ring intact, or, with 5(4)-amino-1H-1:2:3-triazole-4(5)-carboxyamide, ring closure to form the 8-azapurine nucleus. $E$. coli, B. cereus and tobacco mosaic virus (multiplying in $N$. tabacum) differ markedly in their capacity to convert 8-azapurines and 5(4)-amino- $1 H$ 1:2:3-triazole-4(5)-carboxyamide into nucleic acidbound 8-azaguanine. Although we have not directly excluded the possibility that those analogues which were ineffective failed to enter the bacteria, it seems unlikely that such similar types of molecule should differ widely in their ability to penetrate the cell. We consider that the differences we have observed probably reflect differences among the three systems in the metabolic interrelationships of the natural purines and their precursors. One of the most striking of these is shown by the inhibition of $B$. cereus by 8 -azaxanthine, which is incorporated as 8-azaguanine into the bacterial RNA. In all other systems that we have tested 8-azaxanthine is completely inert. It is of interest to compare the specificities of the ribonucleosidases and deaminases known to occur in $B$. cereus. Powell \& Hunter (1956) have shown that disintegrated resting-spore suspensions of $B$. cereus have a ribonucleosidase activity hydrolysing inosine and adenosine but not xanthosine and guanosine. These suspensions also deaminate adenosine but not adenine, guanine or guanosine.

Comparing the action of the 8-azapurines and substituted triazoles on $E$. coli, $B$. cereus and tobacco mosaic virus, we have found that inhibition of bacterial growth or virus development and incorporation of the analogue into RNA as 8-azaguanine are in all cases correlated. Comparison of the effects of 8-azaguanine on $E$. coli and $B$. cereus also shows that the growth inhibition and amount of 8-azaguanine replacement are qualitatively related. These results do not support the view that growth inhibition by the azapurines is largely due to their competitive inhibition of enzymes metabolizing the corresponding natural purines. Friedkin (1952) has shown that 8-azaguanine will form 8-azaguanosine in the following type of reaction catalysed by an enzyme system from horse liver:

Purine + ribose 1-phosphate $\rightleftharpoons$ purine riboside.
Inhibition by 8-azapurines can be more satisfactorily explained by the failure of at least some of the RNA containing 8-azaguanine to function normally. In the case of tobacco mosaic and turnip yellow mosaic viruses the decreased infectivity of preparations containing 8-azaguanine in the virus RNA offers more direct evidence that the biological function of 8-azaguanine containing nucleic acid is impaired (Matthews, 1954, 1955). The demonstration (Creaser, 1955) that 8-azaguanine inhibits the formation of the adaptive enzyme $\beta$-galactosidase in Staphylococcus aureus while allowing synthesis of RNA (containing 8-azaguanine) at the normal rate is also consistent with the view that 8-azaguanine inhibition is largely due to the synthesis of RNA with impaired functions.

8-Azaguanine does not randomly replace guanine residues in the nucleic chains of $B$. cereus RNA. The distribution of 8-azaguanineamong theribonucleaseresistant polynucleotides shows that in the intact nucleic acid 8-azaguanine replacement is greatest in short sequences of adjacent purine residues. The nucleic acid preparations contain a proportion of short polynucleotide chains (about 15-20\%) comparatively rich in 8-azaguanine. The presence of these short chains may explain to some extent the distribution of 8-azaguanine in the ribonucleaseresistant polynucleotides.

The greatest replacement by 8 -azaguanine is in the purine nucleoside $2^{\prime}: 3^{\prime}$-(monohydrogen phosphates) (cyclic nucleotides) found after complete ribonuclease digestion. These originate from those terminal purine nucleotides bearing $2^{\prime}: 3^{\prime}$-(cyclic phosphate) groups and linked by their $5^{\prime}-\mathrm{CH}_{2} \cdot \mathrm{OH}$ groups to neighbouring pyrimidine nucleotide residues (Markham \& Smith, 1952c). This type of end group is found in turnip yellow mosaic virus nucleic acid prepared solely by treatment with ethanol-water solutions at $20^{\circ}$, where its formation by chemical degradation of the nucleic acid during isolation may be precluded. However, we have considered the possibility that the high proportion of 'cyclic' 8-azaguanylic acid terminal residues in the $B$. cereus RNA might be formed during the isolation of the nucleic acid by a preferential rupture of the chains, breaking a $5^{\prime}$ phosphodiester bond distal to an 8-azaguanine residue and forming a cyclic 8-azaguanylic acid end group. Our data do not support such an interpretation. Similar proportions of cyclic azaguanylic acid end groups are obtained from $B$. cereus RNA prepared by any of the three methods we used. In the experiment described in Table 3 the ratio (cyclic guanylic + cyclic 8-azaguanylic acid end groups)/(total RNA guanylic + 8-azaguanylic acids) is the same in RNA preparations containing 3 and $22 \%$ of total 8 azaguanine replacement, and the proportions of 8-azaguanine in the end groups are 17 and $69 \%$ 
respectively. The high proportion of cyclic 8azaguanylic acid terminal groups can be considered as due either to the formation of incomplete RNA chains where further polynucleotide synthesis has been blocked by the presence of an 8-azaguanine terminal residue, or to the more rapid turnover of cyclic purine nucleotide end groups.

The exchange found between guanine and 8azaguanine in $B$. cereus RNA may be compared with that between 5-bromouracil and thymine in $E$. coli DNA (Zamenhof, Reiner, Giovanni \& Rich, 1956). These workers showed that 5-bromouracil supplied to non-dividing cells in a suitable medium was incorporated into the bacterial DNA without any significant increase in the total DNA of the culture. In our experiments the converse type of exchange was studied, namely the replacement of the analogue already incorporated in the nucleic acid by the natural purine. This exchange was accompanied by growth of the cells and increase in total cell RNA. We have not yet elucidated its mechanism or whether it is related to any turnover of RNA which might normally occur in these cells.

One may speculate on the differences between guanine and 8-azaguanine which are responsible for the failure of 8-azaguanine-containing RNA to function normally. The replacement of the $\mathrm{CH}$ group in the purine 8 position by a nitrogen atom changes the shape of the purine ring to a small degree and considerably alters other properties of the molecule. In particular, the dissociation constants of the 6-oxo and 2-amino groups of 8-azaguanine are about $2 \mathrm{pH}$ units lower than those of guanine. This may affect the ability of an 8-azaguanine residue in a nucleic acid to participate in a hydrogen-bonded structure involving these substituent groups. We have considered this as an explanation for the failure of 8-azaguanine to be incorporated into $E$. coli and $\mathrm{T}_{2}$ bacteriophage DNA and the low incorporation observed in $B$. cereus DNA. However, the 5-halogenated uracils which extensively replace thymine in $E$. coli and bacteriophage DNA also have 6-oxo groups with $\mathrm{p} K$ values about 2 units lower than those of thymine. Further study of the properties of nucleic acids containing abnormal bases may help in relating the molecular configuration and function of the natural purines and pyrimidines in nucleic acids.

\section{SUMMARY}

1. Growth of Escherichia coli is inhibited by 8 azaguanine, 8-aza-adenine, 8-azahypoxanthine and 5(4) - amino - $1 H$ - 1:2:3 - triazole -4(5)-carboxyamide. Growth of Bacillus cereus is inhibited by 8-azaguanine and 8-azaxanthine. Development of tobacco mosaic virus in tobacco plants is inhibited by 8-azaguanine, 8-aza-adenine and 5(4)-amino- $1 H$ - 1:2:3-triazole-4(5)-carboxyamide. Other 8-azapurines and substituted triazoles tested in these systems are not inhibitory.

2. In all cases, those 8-azapurines and substituted triazoles which inhibit bacterial growth or virus development are incorporated into the bacterial or virus ribonucleic acid as 8-azaguanine. In $B$. cereus 8 -azaguanine is incorporated in amounts up to $40 \%$ of the ribonucleic acid guanine.

3. The distribution of 8 -azaguanine in $B$. cereus ribonucleic acid is not random. The highest ratio 8-azaguanine/guanine is found in the terminal purine nucleoside $2^{\prime}: 3^{\prime}$-(monohydrogen phosphate) residues liberated by pancreatic ribonuclease. The ratio 8-azaguanine/guanine in the polynucleotides resulting from ribonuclease digestion increases with decreasing polynucleotide size.

4. $B$. cereus ribonucleic acid containing 8azaguanine has been fractionated according to polynucleotide size. The shorter nucleic acid chains contain more 8-azaguanine than the larger chains. They also contain a greater proportion of terminal cyclic 8-azaguanylic acid residues.

5. Addition of guanine to $B$. cereus cells previously grown in the presence of 8-azaguanine results in a rapid replacement by guanine of the 8 -azaguanine in the ribonucleic acid.

6. 8-Azaguanosine and 8-azaxanthosine have been identified in ethanol extracts of $B$. cereus grown in media containing 8-azaguanine.

7. A small amount of 8-azaguanine is incorporated into $B$. cereus deoxyribonucleic acid. 8-Azaguanine deoxyribonucleoside has been tentatively identified in hydrolysates of such nucleic acid. No incorporation of 8-azaguanine could be detected in the deoxyribonucleic acids of $E$. coli or $\mathrm{T}_{2}$ bacteriophage grown in the presence of the analogue.

We wish to thank Dr R. Markham and Dr C. Dekker for valuable discussions, the American Cyanamid Co. and Dr J. Davoll of the Parke Davis Co. for gifts of the synthetic analogues, and the Medical Research Council Unit for Research in Antibiotics, Clevedon, for large-scale preparations of bacteria.

\section{REFERENCES}

Anderson, T. F. (1950). J. appl. Phys. 21, 70.

Creaser, E. H. (1955). Nature, Lond., 175, 899.

Dunn, D. B. \& Smith, J. D. (1954). Nature, Lond., 174, 305. Finkelstein, M. \& Thomas, P. A. (1951). Cancer Res. 11, 801. Friedkin, M. (1952). Fed. Proc. 11, 216.

Gandelman, B., Zamenhof, S. \& Chargaff, E. (1952). Biochim. biophys. Acta, 9, 399.

Herriott, R. M. \& Barlow, J. L. (1952). J. gen. Physiol. 36, 17.

Hitchings, G. H., Elion, G. B., Falco, E. A., Russell, P. B. \& VanderWerff, H. (1950). Ann. N.Y. Acad. Sci. 52, 1318. Hitchings, G. H., Elion, G., Falco, E. A. \& VanderWerff, H. (1947). Abstr. Pap. Amer. Chem. Soc. 112th meeting, 3 c. 
Jeener, R. \& Rosseels, J. (1953). Biochim. biophys. Acta, 11, 438.

Kidder, G. W. \& Dewey, V. C. (1949). J. biol. Chem. 179, 181.

Kidder, G. W., Dewey, V. C., Parks, R. E. \& Woodside, G. L. (1949). Science, 109, 511.

Kidder, G. W., Dewey, V. C., Parks, R. E. \& Woodside, G. L. (1951). Cancer Res. 11, 204.

Kogut, M., Pollock, M. R. \& Tridgell, E. J. (1956). Biochem. J. 62, 391.

Lasnitzki, I., Matthews, R. E. F. \& Smith, J. D. (1954). Nature, Lond., 173, 346.

Law, L. W. (1950). Cancer Res. 10, 186.

Markham, R., Matthews, R. E. F. \& Smith, J. D. (1954). Nature, Lond., 173, 537.

Markham, R. \& Smith, J. D. (1949). Biochem. J. 45, 294.

Markham, R. \& Smith, J. D. (1952a). Biochem. J. 52, 552.

Markham, R. \& Smith, J. D. (1952b). Biochem. J. 52, 558.

Markham, R. \& Smith, J. D. (1952c). Biochem. J. 52, 565.

Marshak, A. \& Vogel, H. J. (1950). Fed. Proc. 9, 85.

Matthews, R. E. F. (1953). J. gen. Microbiol. 8, 277.

Matthews, R. E. F. (1954). J. gen. Microbiol. 10, 521.

Matthews, R. E. F. (1955). Virology, 1, 165.
Matthews, R. E. F. (1956). Biochim. biophys. Acta, 19, 559.

Matthews, R. E. F. \& Smith, J. D. (1954). Biochem. J. 57, vi.

Matthews, R. E. F. \& Smith, J. D. (1956). Nature, Lond., 177, 271.

Powell, J. F. \& Hunter, J. R. (1956). Biochem. J. 62, 381.

Roblin, R. O., Lampen, J. O., English, J. P., Cole, Q. P. \& Vaughan, J. R. (1945). J. Amer. chem. Soc. 67, 290.

Sevag, M. G., Lackman, D. B. \& Smolens, J. (1938). J. biol. Chem. 124, 425.

Shive, W., Ackermann, W. W., Gordon, M., Getzendaner, M. E. \& Eakin, R. E. (1947). J. Amer. chem. Soc. 69, 725.

Smith, J. D. \& Wyatt, G. R. (1951). Biochem. J. 49, 144.

Sugiura, K., Hitchings, G. H., Cavalieri, L. F. \& Stock, C. C. (1950). Cancer Res. 10, 178.

Witkin, E. M. (1951). Cold. Spr. Harb. Symp. quant. Biol. 16, 357.

Wyatt, G. R. (1951). Biochem. J. 48, 584.

Youngner, J. S., Ward, E. N. \& Salk, J. E. (1950). Proc. Soc. exp. Biol., N.Y., 75, 157.

Zamenhof, S. \& Griboff, G. (1954). Nature, Lond., 174, 305.

Zamenhof, S., Reiner, B., Giovanni, R. de \& Rich, K. (1956). J. biol. Chem. 219, 165.

\title{
Adenine Succinic Acid and Adenylsuccinic Acid from Mammalian Liver: Isolation and Identification
}

\author{
By W. K. JOKLIK \\ Department of Microbiology, John Curtin School of Medical Research, \\ Australian National University, Canberra
}

(Received 30 October 1956)

Hurlbert, Schmitz, Brumm \& Potter (1954) have described the chromatography on Dowex columns of purine and pyrimidine derivatives occurring in acid extracts of rat liver. The resolving power of the systems used was considerable, and the separation of a large number of substances was demonstrated. Many of these were characterized, such as mono-, di- and tri-phosphorylated derivatives of guanosine, cytidine and uridine, which appear to be analogous to those of adenosine. Other compounds, including a group of substances containing uridine diphosphate and carbohydrate, were identified tentatively. However, there were a number of compounds which were not investigated beyond determination of the spectrum and phosphate and ribose content, since in most cases they were present in amounts too small for further analysis.

Purine and pyrimidine derivatives have, in recent years, been shown to be constituents of several highly active metabolic intermediates. Examples are: guanosine diphosphate mannose (Cabib \& Leloir, 1954); uridine diphosphate glucose (Caputto, Leloir, Cardini \& Paladini, 1950), and related compounds; cytidine diphosphate choline
(Kennedy \& Weiss, 1955) and cytidine diphosphate ribitol (Baddiley, Buchanan, Carss \& Mathias, 1956); $S$-adenosylmethionine (Cantoni, 1953) and adenosine $3^{\prime}$-phosphate $5^{\prime}$-phosphosulphate (Robbins \& Lipmann, 1956). Many more compounds of this type probably occur. The chromatographic procedure of Hurlbert et al. (1954) is well adapted for the isolation of such substances, and it is not unlikely that some of the compounds detected but not identified by them are purine and pyrimidine derivatives of the type discussed. Thus there would appear to be a need for much further work on the identification of these substances, which occur in traces only.

The isolation and characterization of two ultraviolet-light-absorbing substances occurring in small amounts in acid extracts of mouse and rabbit liver is reported in this paper. They are adenine succinic acid [6-(1:2-dicarboxyethylamino)purine] and adenylsuccinic acid [6-(1:2-dicarboxyethylamino-9-ribo$5^{\prime}$-phosphate)purine]. These two substances are related in the same way as adenine and $5^{\prime}$-adenylic acid (AMP-5'). No nucleoside corresponding to these compounds was detected. Adenine succinic acid has 